\title{
Developing construct 2 android-based education math game to improve the ICT literacy on number patterns subject
}

\author{
Arif Fatahillah $^{1}$, Nur Alfiyantiningsih ${ }^{1}$, Dafik ${ }^{1}$ \\ ${ }^{1}$ University Jember, Indonesia \\ $₫$ nnuralfi1998@gmail.com*
}

\section{Article Information}

Submitted January 06, 2021

Revised February 25, 2021

Accepted April 01, 2021

Keywords

Android;

Educational Game;

ICT Literacy;

Number Patterns

\begin{abstract}
This research aimed to describe the development process and results of the Construct 2 Android-based education math game on number pattern subjects to increase student's ICT literacy. This research employed the Research and Development method with a 4-D development model. The development model consisted of 4 stages: the Define stage, the Design stage, the Development stage, and the dissemination stage. Also, the researchers developed the Android-based application based on ICT literacy indicators. The application must be valid, practical, and effective. The results showed a correlation coefficient value of 0.87 and included in the valid category with very high interpretation. The level of practicality of the developed product was $83.96 \%$ based on a users' responses questionnaire. The effectiveness was determined based on the percentage of students' learning outcomes which was $83.33 \%$. The increase in students' ICT literacy was determined based on the ICT literacy questionnaire and learning outcome tests' average N-Gain score. The average $\mathrm{N}$-Gain value obtained was 0.75 , with an average value for the ICT literacy questionnaire of 0.89 and the average value for the learning outcome test of 0.61 . Based on these three criteria, it can be concluded that the Construct 2 android-based educational math game on the number pattern material can improve students' ICT literacy.
\end{abstract}

\section{INTRODUCTION}

The technological development of the industrial revolution era 4.0 combines physical and digital technology through analytics, artificial intelligence, cognitive technology, and the Internet of Things (IoT). One of the fields that have been influenced is education through Elearning (electronic learning). Thus, teachers must adapt to technology to improve students' learning skills (Kayalar, 2016). Technology in learning can make students feel more enthusiastic about learning and understanding the material (Nurdyansyah \& Riananda, 2016). Therefore, teachers' role is essential in the effectiveness of technology in the learning process (Kayalar, 2016).

Technology in education can be used in ICT learning (Information and Communication Technology). ICT-based understanding is expected to motivate teachers during the learning process. However, based on the results of observations conducted at schools, the use of technology in classroom learning was still not optimal. ICT is an ability that students must possess (Muawiyah et al., 2018). ICT literacy can use digital technology as a tool to access, manage, integrate, evaluate, and create (Garba, 2014). Broadly, ICT can be defined as computers, internet, telephone, radio, and audiovisual equipment (Pernia, 2008).

\begin{tabular}{ll}
\hline How to cite & Fatahillah, A., Alfiyantiningsih, N., \& Dafik, D. (2021). Developing Construct 2 Android-Based Education Math \\
& Game to Improve the ICT Literacy on Number Patterns Subject. Al-Jabar: Jurnal Pendidikan Matematika, 12(1), \\
& $25-34$. \\
E-ISSN & $2540-7562$ \\
Published by & Mathematics Education Department, UIN Raden Intan Lampung.
\end{tabular}


ICT-based learning media can be the internet, intranet, smartphone, and CD room/flash disk (Suci et al., 2019). Smartphones are currently overgrowing and have become a trend among Indonesians. Based on Statista Research Development data, smartphone users in Indonesia reached 81.87 million people, and $92.14 \%$ of Indonesians use the Android operating system on their mobile devices. The percentage is higher than other operating systems (Department, 2020b, 2020a). For education, smartphones can bring about positive and negative impacts. One of the positive effects is that the smartphone can be used as an innovation in the classroom (Faraweh \& Jusoh, 2017). Contrary, smartphones' negative impacts are the usage, the students' discipline, and misuses during the learning process (Yuni \& Pieewan, 2016). To overcome the negative impacts, smartphones should be used as a medium of ICT-based learning in Androidbased educational games in the classroom.

Game is an innovation of technological development evidenced by the emergence of many online games such as Mobile Legend, PUBG Mobile, Free Fire, etc. Currently, online games are used as entertainment by various groups of people (Novrialdy, 2019). Many students play online games as entertainment - however, many students play games excessively. One of the effects is decreasing students' concentration at school or home (Husna et al., 2017; Novrialdy, 2019). Games can also positively impact, for instance, solving problems, learn languages, increase concentration, focus, and improve visual abilities. The visualization in the game is more interesting than the text in the book. It can be said that games are quite useful in helping teachers explain the material if they develop the educational games.

Educational games can be used as alternative media in learning activities. The educational game can be beneficial for students to understand the learning material compared to the usual learning. Games can also help students study outside the school time (Enkasyarif \& Agustia, 2017; Huizenga et al., 2019; Nugraha et al., 2018). However, games should be used following the material to be covered and the learning objectives. Also, there is information in educational games that can be useful for learning (Kidi et al., 2017; Muhtasyam, 2018; Wulandari et al., 2016). The development of educational games can be done using a variety of software. Construct 2 is one of the software that can be used to develop educational games. Construct 2 is a game developer software with 2-dimensional graphics with a drag and drop system and can be used without using programming code and published on several platforms (Rahadi et al., 2016; Yustin et al., 2016).

Mathematics is a subject that has an essential role in education because it underlies other sciences (Muhtasyam, 2018). One of the materials contained in mathematics is number patterns. However, some students have difficulty finding the main idea of the problem and making abstract generalizations (Handayani et al., 2015). Besides, students have a hard time determining the pattern or the nth term in a pattern of numbers. It is proven by students' incorrectly deciding the pattern of numbers (Sari et al., 2018). Therefore, a learning medium is needed to teach number patterns to students (Sulistyawati et al., 2018).

Based on several studies, educational games' development was only focused on the material or topic being discussed. Also, educational games do not show the material discussed during the mission (Saputro et al., 2018; Yustin et al., 2016). In this development research, the educational game had been developed using the Construct 2 software adjusted to the ICT literacy indicator. 
Based on the problem's background, the researchers aimed to develop a Construct 2 Android-based game on number patterns material to improve students' ICT literacy. The game's type was the platformer game, so students can learn the material by following the instruction provided. Moreover, the game was developed by following the ICT literacy indicators to understand the material and improve their ICT literacy. It is expected that the developed educational games can make mathematics learning more fun and make students comfortable to learn.

\section{METHODS}

This research employed the Research and Development (RnD) method with the 4-D development model. The research subjects consisted of 24 students of class IX-E at SMP Nuris Jember. The development model consisted of 4 stages (Thiagarajan, 1974), as presented in Figure 1.

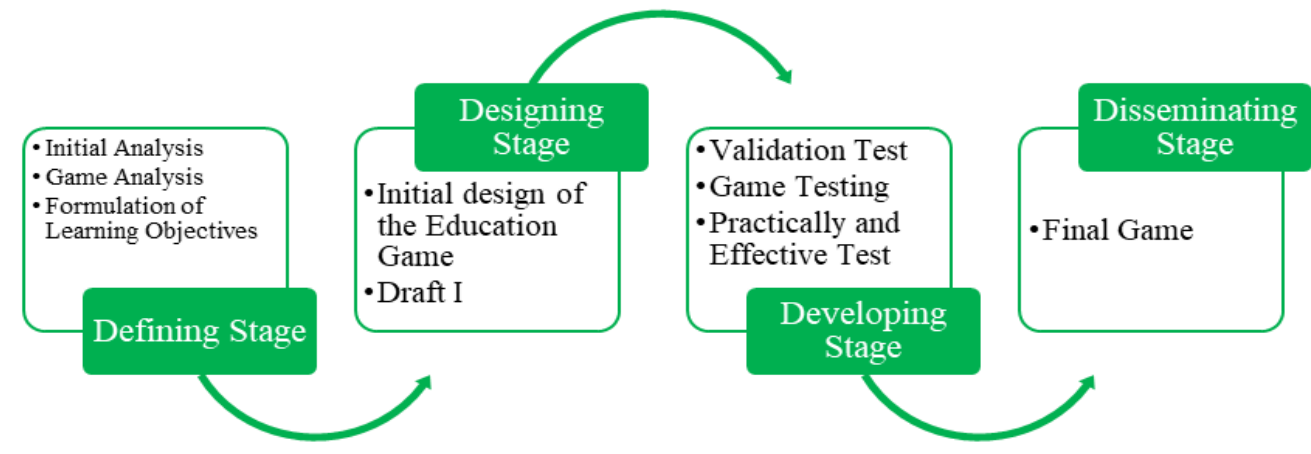

Figure 1. The Research Method Flowchart

According to Nieveen, the developed product should be tested for validity, practicality, and effectiveness (Kurnianto, 2019). Three validators assessed the validity based on three aspects: format, contents aspects, and language aspect (Yamasari, 2010). The educational game is valid if it gets a very high level of validity or higher. The practicality was determined based on the questionnaire responses and interviews. The developed educational game is practical if it meets the excellent category. Educational games' effectiveness was determined by $80 \%$ of students' learning outcomes that pass minimum mastery criteria. Also, the increase in ICT literacy is shown by the N-Gain test of learning outcomes and questionnaires before and after applying the educational game. The results of observations during the trial and the results of observations during the educational game testing are the supporting data.

Table 1. The Level of Media Practicality

\begin{tabular}{cc}
\hline P-Value & Percentage Category \\
\hline $\mathrm{P}>95 \%$ & Excellent \\
$80 \%<\mathrm{P} \leq 95 \%$ & High \\
$65 \%<\mathrm{P} \leq 80 \%$ & Moderate \\
$50 \%<\mathrm{P} \leq 65 \%$ & Low \\
$\mathrm{P}<50 \%$ & Poor \\
\hline Table 2. The Criteria of Normalized N-Gain Index (Hake, 1999) \\
\hline Normalized $N$-Gain & Interpretation \\
\hline $\mathrm{g}>0,7$ & High \\
$0,3 \leq \mathrm{g} \leq 0,7$ & Moderate \\
$\mathrm{g}<0,3$ & Low \\
\hline
\end{tabular}




\section{RESULTS AND DISCUSSION}

The educational game was developed using Research and Develop (RnD) method with the 4-D model. The model consisted of four stages: Define stage, Design stage, Develop, and Disseminate stage. The description of the stages are as follows:

\section{Define Stage}

This stage aims to determine the students' needs toward the educational games to be developed. This stage consisted of the initial analysis stage. The analysis resulted in the lack of students' ICT uses especially smartphones. It was also found that the students had never used educational games as a learning tool. The objective of the research was to improve students' ICT literacy skills on number pattern material.

\section{Design Stage}

The design stage aimed to design an educational game that consisted of media selection, the selection format, the preliminary design, and the preparation of tests. The researchers chose the Android-based mathematics educational game because it became one of the attractions for students to improve their ICT literacy and make learning math attractive. The game was developed using the Construct 2 software. The android game was developed in the .apk format. It can be downloaded via Google Play Store, making it easier to access and install the game.

The mathematics education game's initial design contained the concept following the ICT literacy indicators and game assets needed. The following is the modified ICT literacy indicator from the Educational Testing Service (ETS) (Panel, 2002).

Table 3. ICT Literacy Indicator

\begin{tabular}{lll}
\hline \multicolumn{1}{c}{$\begin{array}{c}\text { ICT Literacy } \\
\text { Component }\end{array}$} & \multicolumn{1}{c}{ Definition } & \multicolumn{1}{c}{ Indicator } \\
\hline Access & $\begin{array}{l}\text { Knowing about and knowing how } \\
\text { to collect and/or retrieve } \\
\text { information. }\end{array}$ & $\begin{array}{l}\text { 1. Open the educational game on } \\
\text { the smartphone. }\end{array}$ \\
Manage & $\begin{array}{l}\text { Applying an existing } \\
\text { infoss the play, tutorial, and } \\
\text { inganizational or classification } \\
\text { scheme. }\end{array}$ & $\begin{array}{l}\text { 3. Press the start button and the } \\
\text { navigation button. }\end{array}$ \\
Integrate & $\begin{array}{l}\text { Interpreting and representing } \\
\text { information related to the ability } \\
\text { to summarize, compare, and } \\
\text { contrast. }\end{array}$ & $\begin{array}{l}\text { Playing the education game. } \\
\text { - Collect the circles of known } \\
\text { number pattern }\end{array}$ \\
& $\begin{array}{l}\text { - Continue the number pattern } \\
\text { terms in the sequence. }\end{array}$ \\
& $\begin{array}{l}\text { - Determines the term of the } \\
\text { unknown number pattern }\end{array}$ \\
Evaluate & $\begin{array}{l}\text { Answer the question at each level } \\
\text { and determine the nth term } \\
\text { usefulness, or efficiency of the } \\
\text { information. } \\
\text { Generating information by } \\
\text { adapting, applying, designing, } \\
\text { inventing, or authoring } \\
\text { information. }\end{array}$ & $\begin{array}{l}\text { Using information that has been } \\
\text { obtained from the educational } \\
\text { game. }\end{array}$ \\
\hline
\end{tabular}

The developed education game is a platformer game with one type of action game where the character has to jump to pass obstacles. At levels 1 to 5 , students are designed to collect a 
predetermined number pattern and continue to the next unknown number pattern. After determining the pattern of numbers in each level, questions related to the previous level will appear. Then, at level 6 (the final level), the students are asked to draw up an incomplete image pattern then determine the $\mathrm{n}$-th formula.

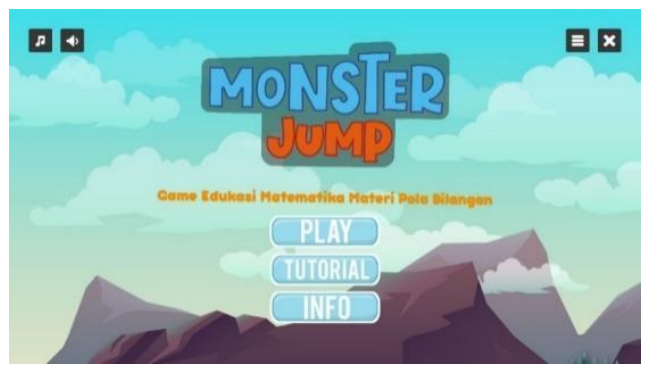

Figure 2. Main Menu Display

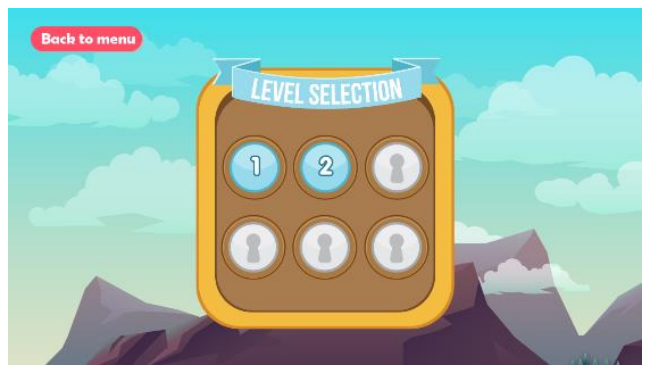

Figure 4. Menu Level Display

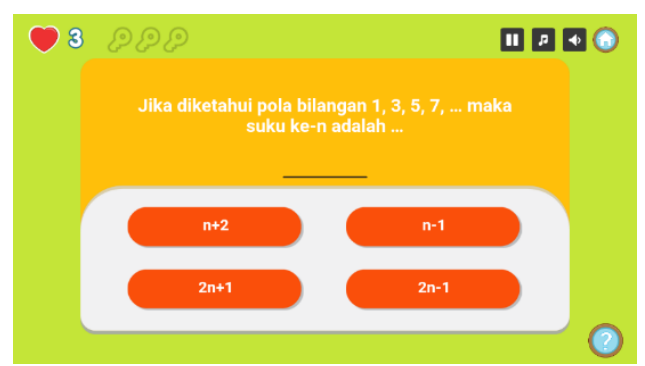

Figure 6. Question Display

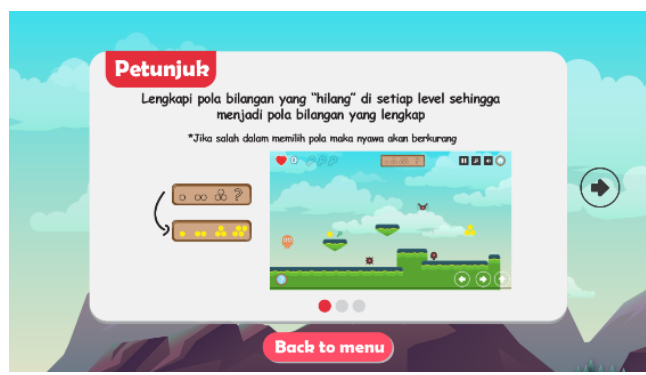

Figure 3. Tutorial Menu Display

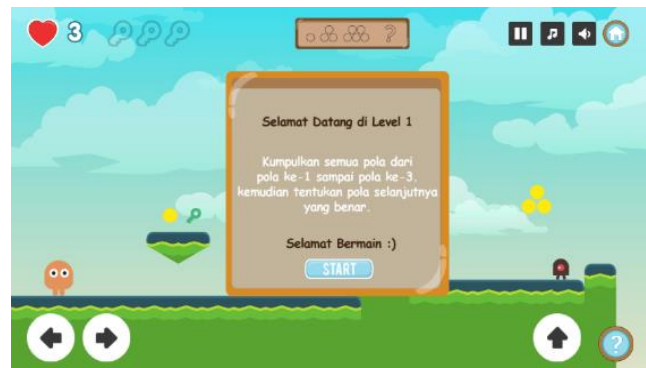

Figure 5. Game Display

The pretest and the posttest developed in the study focused on the number pattern material. The developed tests consisted of 5 description questions. The tests had been adjusted to the modified ICT literacy indicators.

\section{Develop Stage}

The development stage was carried out by conducting expert validation and testing. The experts' validation produced a valid educational game and deserved to be tested. The trial was conducted to determine the practicality, effectiveness, and improvement of students' ICT literacy.

\section{Disseminate Stage}

The dissemination was the last stage after the educational game met the validity, practicality, and effectiveness requirements. The game was distributed through Google Play Store. The Google Play Store was selected because of its accessibility.

\section{The Validity}

Three aspects determined the validity: format, contents, and language. Based on the validator's assessment, the correlation coefficient $(\alpha)$ was 0.87 , which indicated that this educational game 
was valid within the excellent category. Learning media with excellent validity criteria is suitable for the learning process (Murtikusuma et al., 2019; Mareta et al., 2019).

\section{The Practicality}

The practicality data were obtained from the questionnaire responses. Educational games are practical if the average percentage of user responses shows a good or excellent category. The results obtained were $83.96 \%$, indicating that the educational game was included in the "good" category. Here are the criteria and the results of the questionnaire.

Table 4. The Questionnaire Responses

\begin{tabular}{|c|c|c|c|c|c|}
\hline \multirow{2}{*}{ No } & \multirow{2}{*}{ Indicators } & \multicolumn{4}{|c|}{$\begin{array}{c}\text { Percentage of the Students Response of Each } \\
\text { Category }(\%)\end{array}$} \\
\hline & & $\begin{array}{l}\text { Strongly } \\
\text { Agree }\end{array}$ & Agree & Disagree & $\begin{array}{l}\text { Strongly } \\
\text { Disagree }\end{array}$ \\
\hline 1 & $\begin{array}{l}\text { I can open the education game "Monster } \\
\text { Jump" easily }\end{array}$ & 62,50 & 37,50 & 0,00 & 0,00 \\
\hline 2 & $\begin{array}{l}\text { I was happy to study by using the education } \\
\text { game "Monster Jump." }\end{array}$ & 45,83 & 50,00 & 4,17 & 0,00 \\
\hline 3 & $\begin{array}{l}\text { I wasn't feeling bored studying the lesson } \\
\text { by using this education game, "Monster } \\
\text { Jump." }\end{array}$ & 45,83 & 54,17 & 0,00 & 0,00 \\
\hline 4 & $\begin{array}{l}\text { I was motivated to learn mathematics after } \\
\text { using the education game "Monster Jump." }\end{array}$ & 20,83 & 66,67 & 12,50 & 0,00 \\
\hline 5 & $\begin{array}{l}\text { I was motivated to learn pattern number } \\
\text { subjects by using the education game } \\
\text { "Monster Jump." }\end{array}$ & 37,50 & 50,00 & 8,33 & 4,17 \\
\hline
\end{tabular}

Based on Table 4, the students felt motivated to learn math using the developed educational game. Therefore, technology as a learning medium affects the learning outcome and students' learning interest. The data obtained through user response questionnaires and interviews proved that the educational game was practical to use (Murtikusuma et al., 2019; Kurnianto, 2019).

\section{The Effectiveness}

The effectiveness of educational games was determined by the test results measuring students' understanding of the material. The test results obtained a completeness percentage of $83.33 \%$ from 24 students with the minimum competency criteria of 75 . This percentage shows that the developed educational games can improve students' learning outcomes (Saputro et al., 2018; Yustin et al., 2016).

\section{ICT Literacy Improvement}

The improvement of students' ICT literacy was determined by the N-Gain test on learning outcomes and ICT literacy questionnaires before and after using the developed educational game. The results of the ICT literacy questionnaire and learning outcome tests showed an increase. The N-Gain analysis results were 0.61 and 0.89 , so that the average N-Gain value was 0.75. It can be concluded that the developed educational games can improve students' ICT literacy skills.

Table 5. The Average N-Gain Value of the Test and Questionnaire

\begin{tabular}{cccc}
\hline Average & Before & After & $N$-Gain \\
\hline
\end{tabular}




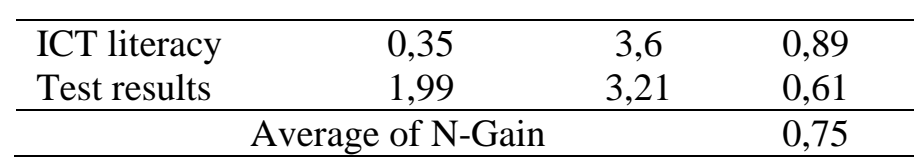

Table 6. The N-Gain on Each ICT Literacy Component

\begin{tabular}{cccc}
\hline Components & Before & After & $\boldsymbol{N}$-Gain \\
\hline Access & 0,44 & 4,00 & 1,00 \\
Manage & 0,33 & 3,83 & 0,95 \\
Integrate & 0,50 & 3,83 & 0,95 \\
Evaluate & 0,16 & 3,33 & 0,83 \\
Create & 0,33 & 3,00 & 0,73 \\
\hline
\end{tabular}

Table 6 shows the increase in every ICT literacy aspect before and after using the developed educational games. Moreover, each aspect's N-Gain value is included in the high category because of $\mathrm{g}>0.7$. It can be said that the educational game can improve students' ICT literacy. The educational game helped students understand number pattern material and improve their ICT literacy. Students can use educational games as a medium for learning number pattern material in a fun way to encourage their participation in learning (Gros, 2007).

Table 6 shows an increase in every aspect of ICT literacy, namely access, manage, integrate, evaluate, and create. The improvement of ICT literacy can be influenced by the students' ability to use the technology and increase their knowledge (Adetimirin, 2012; Santos, 2019). Most students can easily open and access the instructions of the game. It means that students know how to collect information before proceeding to the next stage (Mustika, 2013).

Mathematic educational games with number pattern material can make students more interested and know more about the material than before playing educational games (Huizenga et al., 2019). It can facilitate students in understanding the abstract idea (Sulistyawati et al., 2018). Students can interpret different information obtained at each level of the game, especially on the various displayed number patterns. At each level of the game, the students gain information about number patterns. In the box, there are several known and abstract number pattern terms. Students complete the number pattern by choosing a number pattern that has been provided. If they choose the wrong choice, the character's health will decrease. When the health runs out, the students have to repeat the level. The repetition process can make students better understand the material. Moreover, playing educational games, knowing the buttons' use, and combining the information obtained can promote ICT literacy. Thus, it can be interpreted that knowledge can help improve students' ICT literacy (Adetimirin, 2012).

After completing each level, a multiple choices question will appear containing the number pattern material at the levels that have been completed. Besides, at level 6 , the students are asked to look for the nth term formula for a specific number pattern. Before looking for the nth term, the students must first complete the pictures to form a pattern. After completing the pattern, students are required to fill in the blank spots that have been provided. They will assess or evaluate the usefulness of the information they get to work on the problems. It means that using knowledge and information interactively requires a person to recognize and determine what is not known; identify, locate, and access the appropriate resources; evaluate the quality, relevance, and value of such information and its source; and organize knowledge information (Kim et al., 2014). 
Students take a learning outcome test after completing the educational game. The learning outcome test consisted of five description questions adjusted to the material in the educational game. Some students had difficulty working on number pattern questions (Sari et al., 2018). This difficulty was shown by the use of incorrect formulas or not writing the formula. The test results obtained a completeness percentage of $83.33 \%$ of 24 students with a minimum completeness criteria of 75 . The percentage showed that there was an increase in the ICT literacy aspect. Students' ICT literacy skills can be trained and improved using technology. Students' ICT literacy can also affect learning test results. Based on Yustin et al., using educational games in mathematics learning can improve learning outcomes by $32 \%$ compared to students who do regular learning by only $28 \%$ (Yustin et al., 2016). Another study conducted by Saputro et al. also showed a moderate increase in students' learning outcomes as indicated by the N-Gain value of 0.49 (Saputro et al., 2018). Therefore, ICT literacy can help students learn more effectively and help them find knowledge related to the information they want to learn (Ghavifekr \& Rosdy, 2015).

\section{CONCLUSIONS}

Based on the data analysis, it can be concluded that the Construct 2 Android-based educational game on number pattern material can improve students' ICT literacy skills. The validity of the developed educational game was 0.87 which is included in the valid category with excellent interpretation. The practicality of the developed educational games obtained $83,96 \%$, which is included in the good category. The effectiveness of the developed educational games, determined by the percentage of students' test results, was $83.33 \%$ ( 24 students). Based on the analysis, the test results and the ICT literacy questionnaire's N-Gain values before and after implementing the educational game were 0.61 and 0.89 , with an average $\mathrm{N}$-Gain of 0.75 . Therefore, it can be concluded that the developed educational game can improve students' ICT literacy.

The researchers suggest those who will develop a game to decrease and resolve the bug better. For the next research, it is recommended to develop various types of games in other mathematics material so that the students are interested and can increase ICT literacy.

\section{AUTHOR CONTRIBUTIONS STATEMENT}

AF represents data collection and instrument design. then assisted by NA and DD in compiling the article.

\section{REFERENCES}

Adetimirin, A. E. (2012). ICT literacy among undergraduates in Nigerian universities. Education and Information Technologies, 17(4), 381-397.

Enkasyarif, M. D., \& Agustia, R. D. (2017). Pembangunan game edukasi "petualangan kolev" sebagai media pembelajaran matematika berbasis android (studi kasus SMPN 1 Tanjungsari). J. Ilm. Komput. dan Inform, 1-8.

Garba, S. A. (2014). Impact of ICT course on pre-service teachers acquisition of ICT literacy skills and competence in Nigeria. International Journal of Modern Education Research, 1(2), 37-42. 
Ghavifekr, S., \& Rosdy, W. A. W. (2015). Teaching and learning with technology: effectiveness of ICT integration in schools. International Journal of Research in Education and Science, 1(2), 175-191.

Gros, B. (2007). Digital games in education: the design of game-based learning integration of digital games in learning and e- learning environments: connecting experiences and context. Journal of Research on Technology in Education, 40(1), 23-38.

Hake, R. R. (1999). Analyzing change/gain scores. Division D, 1-4.

Handayani, S., Putri, R. I. I., \& Somakim. (2015). Pemanfaatan lego pada pembelajaran pola bilangan. Jurnal Didaktik Matematika, 2(1), 21-32.

Huizenga, J., Admiraal, W., Dam, G. ten, \& Voogt, J. (2019). Mobile game-based learning in secondary education: Students' immersion, game activities, team performance and learning outcomes. Computers in Human Behavior, 99(November 2018), 137-143.

Husna, N., Normelani, E., \& Adyatma, S. (2017). Hubungan bermain games dengan motivasi belajar siswa sekolah menengah pertama (SMP) di kecamatan Banjarmasin Barat. JPG (Jurnal Pendidikan Geografi), 4(3), 1-14.

Kidi, N., Kanigoro, B., Salman, A. G., Prasetio, Y. L., Lokaadinugroho, I., \& Sukmandhani, A. A. (2017). Android based indonesian information culture education game. Procedia Computer Science, 116, 99-106.

Kim, H. S., Kil, H. J., \& Shin, A. (2014). An analysis of variables affecting the ICT literacy level of Korean elementary school students. Computers \& Education, 77, 29-38.

Kurnianto, W. A. (2019). Pengembangan media pembelajaran matematika berbasis game PC (Personal Computer) berbantuan software kodu game lab pada materi pola bilangan. Universitas Jember.

Ma'azer Al Fawareh, H., \& Jusoh, S. (2017). The use and effects of smartphones in higher education. Ijim, 11, 103-168.

Mareta, I., Dafik, D., \& Murtikusuma, R. P. (2020). The development of fotonovela learning media assisted by Ms Publisher on Arithmetic Sequence and Progression. Pancaran Pendidikan, 8(2), 1-8.

Muawiyah, D., Yamtinah, S., \& Indriyanti, N. Y. (2018). Higher education 4.0: Assessment on environmental chemistry course in blended learning design. Journal of Physics: Conference Series, 1097(1), 0-7.

Muhtasyam, A. (2018). Pengembangan media pembelajaran matematika berupa game edukasi berbasis android dengan bantuan software construct 2. UIN Syarif Hidayatullah Jakarta.

Murtikusuma, R. P., \& Hermawan, L. I. (2019, July). Development of e-comic using pixton and kelase web on linear program of two variables assisted by geogebra. In Journal of Physics: Conference Series (Vol. 1265, No. 1, p. 012010). IOP Publishing.

Murtikusuma, R. P., Fatahillah, A., Oktavianingtyas, E., Hussen, S., \& Lailiya, N. (2019, March). The development of interactive mathematics learning media based on schoology and visual basic through industrial revolution 4.0. In IOP Conference Series: Earth and Environmental Science (Vol. 243, No. 1, p. 012137). IOP Publishing.

Mustika, E. (2013). Pembelajaran sains berbasis ICT untuk meningkatkan ICT literacy siswa sekolah dasar. Pedagogik (Jurnal Pendidikan Sekolah Dasar), 1(2), 30-40..

Novrialdy, E. (2019). Kecanduan game online pada remaja: Dampak dan pencegahannya. Buletin Psikologi, 27(2), 148-158. 
Nugraha, R. G. A., Florentinus, T. S., \& Utomo, K. B. (2018). Lagu nusantara: android role playing game for elementary school music learning. Journal of Primary Education, 7(2), 137-145.

Nurdyansyah, N. (2016). Developing ict-based learning model to improve learning outcomes ipa of sd fish market in sidoarjo. Jurnal Tekpen, 1(2), 929-940.

Panel, I. L. (2002). Digital transformation: A framework for ICT literacy. Educational Testing Service, 1(2), 1-53.

Pernia, E. E. (2008). Strategy framework for promoting ICT literacy in the Asia-Pacific region. Publication of UNESCO Bangkok communication and information unit. Asia and Pacific regional bureau for education, Bangkok, 10110.

Rahadi, M. R., Satoto, K. I., \& Windasari, I. P. (2016). Perancangan game math adventure sebagai media pembelajaran matematika berbasis android. Jurnal Teknologi Dan Sistem Komputer, 4(1), 44-49.

Santos, G. M., Ramos, E. M., \& Reis, M. J. (2019). ICT literacy and school performance. Turkish Online Journal of Educational Technology-TOJET, 18(2), 19-39.

Saputro, T. A., Kriswandani, K., \& Ratu, N. (2018). Pengembangan media pembelajaran mengunakan aplikasi construct 2 pada materi aljabar kelas VII. JP2M (Jurnal Pendidikan Dan Pembelajaran Matematika), 4(1), 10-23.

Sari, N. I. P., Subanji, S., \& Hidayanto, E. (2018). Diagnosis kesulitan penalaran matematis siswa dalam menyelesaikan masalah pola bilangan. Jurnal Kajian Pembelajaran Matematika, 2(2), 64-69.

Statista Research Department. (2020a). Share of Mobile Operating System in Indonesia. https://www.statista.com/statistics/262205/market-share-held-by-mobile-operatingsystems-in-indonesia/

Statista Research Department. (2020b). Smartphone Users in Indonesia 2015-2025. https://www.statista.com/statistics/266729/smartphone-users-in-indonesia/

Suci, N. W., Hobri, \& Murtikusuma, R. P. (2019). Pengembangan media pembelajaran untuk siswa SMP kelas VII materi perbandingan berbasis game android berbantuan software gamesalad. Universitas Jember.

Sulistyawati, A., Wardono, W., \& Kartono, K. (2018, February). Pemanfaatan ICT dalam literasi matematika. In PRISMA, Prosiding Seminar Nasional Matematika (Vol. 1, pp. 853-859).

Thiagarajan, D. S. S. (1974). Instructional Development for Training Teachers of Exceptional Children: A Sourcebook (Issue Mc). Indiana University.

Wulandari, R., Susilo, H., \& Kuswandi, D. (2016). Multimedia interaktif bermuatan game edukasi sebagai salah satu alternatif pembelajaran IPA di sekolah dasar. Jurnal Pendidikan, 2(8), 1-8.

Yamasari, Y. (2010). Pengembangan media pembelajaran matematika berbasis ICT yang berkualitas. In Seminar Nasional Pascasarjana X-ITS, Surabaya (Vol. 4).

Yuni, R. S., \& Pieewan, A. C. (2016). hubungan intensitas penggunaan smartphone dengan disiplin belajar siswa. Jurnal Pendidikan Sosiologi, 1-16.

Yustin, J. A., Sujaini, H., \& Irwansyah, M. A. (2016). Rancang Bangun Aplikasi Game Edukasi Pembelajaran Matematika Menggunakan Construct 2. Jurnal Sistem Dan Teknologi Informasi (JUSTIN), 1(1), 422-426. 